\title{
Penerapan Solution-Focused Brief Counseling (SFBC) untuk Meningkatkan Konsep Diri Akademik Siswa
}

\author{
Ahmad Heri Nugroho \\ Jurusan Bimbingan dan Konseling, Fakultas Ilmu Pendidikan, Universitas Negeri Semarang \\ e-mail : hersev.scout7@gmail.com \\ Diah Ayu Puspita \\ Jurusan Bimbingan dan Konseling, Fakultas Ilmu Pendidikan, Universitas Negeri Semarang \\ e-mail : diahayaumustofa@gmail.com \\ Mulawarman \\ Jurusan Bimbingan dan Konseling, Fakultas Ilmu Pendidikan, Universitas Negeri Semarang
}

\begin{abstract}
ABSTACT
The concept of self-academic becomes one of the important actors in the formation of student identity to achieve success in the academic field. Several cases of students truancy to quit school on the grounds of disliking certain subjects are suspected due to a lack of students' understanding of their own academic selfconcept, so that this can lead to decreased learning outcomes and student failure. Guidance and counseling as a component of schooling can actually play a role in helping students improve academic self-concept. One of the activities of counseling and guidance services that can be implemented is individual counseling activities. Of course to achieve maximum results required a special technique or approach. The approach that can be used is the Solution-Focused Brief Counseling (SFBC) approach, through this approach the students will collaborate with the counselor to focus on finding solutions so that they can make changes to themselves as individuals who have positive self-concept. The approach focuses on building solutions so that with the solutions found, students can be briefly to assist with the completion of their developmental tasks.
\end{abstract}

\begin{abstract}
ABSTRAK
Konsep diri akademik menjadi salah satu pemeran penting dalam pembentukan identitas diri siswa untuk mencapai keberhasilan dalam bidang akademik. Beberapa kasus siswa membolos hingga berhenti sekolah dengan alasan tidak menyukai mata pelajaran tertentu ditengarai akibat kurangnya pemahaman para siswa mengenai konsep diri akademik mereka sendiri, sehingga hal ini dapat menimbulkan menurunnya hasil belajar hingga kegagalan pada siswa. Bimbingan dan konseling sebagai komponen pendidikan disekolah sesungguhnya dapat mengambil peranan dalam membantu siswa meningkatkan konsep diri akademik. Salah satu kegiatan layanan bimbingan dan konseling yang dapat dilaksanakan adalah kegiatan konseling individu. Tentu untuk mencapai hasil yang maksimal dibutuhkan teknik atau pendekatan khusus. Adapun pendekatan yang dapat digunakan adalah pendekatan Solution-Focused Brief Counseling (SFBC), melalui pendekatan ini siswa akan berkolaborasi dengan konselor untuk berfokus menemukan solusi sehingga bisa melakukan perubahan pada diri menjadi individu yang memiliki konsep diri positif. Pendekatan berfokus pada pembangunan solusi sehingga dengan solusi yang ditemukan, siswa bisa secara singkat untuk membantu penyelesaian tugas perkembangannya.
\end{abstract}

Kata kunci : konsep diri akademik, pendekatan Solution-Focused Brief Counseling (SFBC)

\section{PENDAHULUAN}

Remaja adalah masa dimana mulainya untuk menetapkan ego identitas pada dirinya, namun banyak remaja yang mengalami krisis identitas pada dirinya. Krisis identitas terjadi kepada remaja karena konsep diri pada remaja masih dalam keadaan yang labil, terkadang posistif dan terkadang menjadi negatif (Gunanto, Sutoyo, dan Rahman, 2013 : 19). Sehingga, hal tersebut membuat para remaja mengalami krisis antara identitas dan kebingungan identitas dirinya (Erikson dalam Feist dan Feist, 2013:303). Dengan demikian dalam proses untuk membentuk identitas diri remaja perlu meningkatkan konsep diri positif 
agar bisa menyelesaikan tugas-tugas perkembangannya yaitu penerimaan gambaran fisik mereka, penerimaan peran seksual, kemandirian ekonomi, dan konsep terhadap ketrampilan dalam pendidikan (Hurlock, 2003:209).

Konsep diri akademik merupakan bagian dari konsep diri. Menurut Lent, Brown, \& Gore, sebagaimana dikutip oleh Cokley (2000:149) konsepdiri akademik didefinisikan sebagai sikap, perasaan dan persepsi relatif terhadap satu adalah keterampilan intelektual atau akademik. Diperkuat oleh Dagnew (2015:216) Konsep diri akademik didefinisikan sebagai bagaimana seseorang merasakkan tentang dirinya sendiri dalam sekolah atau seting akademik, atau dalam kaitannya dengan kemajuan akademis siswa.

Konsep diri akademik yang positif akan mendorong siswa menjadi optimal pada masa belajarnya. Menurut Shevelson dan Bolus, sebagaimana dikutip oleh Saifullah (2015:251) siswa yang memeliki konsep diri positif memiliki konsep positif untuk mampu melakukan penerimaan diri, kepercayaan diri, dan penghargaan diri yang berkaitan dengan bidang akademik yang digeluti di sekolah.

Namun menurut beberapa penelitian konsep diri akademik siswa menjadi kurang posistif. Hal tersebut menurut Argyle, sebagaimana dikutip oleh Budiarsih dan Zen (2016:115) karena terdapat empat faktor yang sangat berkaitan yang berpengaruh terhadap perkembangan konsep diri, yaitu reaksi dari orang lain, pembandingan dengan orang lain, peranan seseorang dan identifikasi terhadap orang lain. Sedangkan dari penelitian yang dilakukan oleh Budiarsih dan Zen (2016:116) menyimpulkan bahwa konsep diri akademik negative siswa muncul akibat adanya perbandingan dengan teman-teman yang lebih pintar. Perbandingan yang dibuat siswa merupakan perwujudan evaluasi negatif siswa terhadap dirinya yang menyebabkan perilaku negatif pula.

Konsep diri akademik merupakan tugas perkembangan yang harus dipenuhi oleh individu pada masa belajarnya. Pendekatan Solution-Focused Brief Counseling (SFBC) bisa menjadi alternatif untuk dilaksanakan pada seting sekolah debagai wadah pengembangan konsep diri akademik siswa karena pada seting pendidikan akan lebih efektif dengan adanya suatu terapi yang digunakan dalam waktu yang singkat juga adanya kolabolasi dengan berbagai pihak yang terkait. Menurut penelitian dari Franklin, Moore, \& Hopson (2008:26) menyatakan intervensi untuk dilakuan di sekolah sebaik dengan jangka waktu yang pendek dan memuat suatu perubahan. Intervensi untuk mendukung gagasan tersebut yaitu dengan menggunakan SFBC.

Dengan Solution-Focused Brief Counseling $(S F B C)$ konselor bisa berkolaborasi dengan siswa untuk meningkatkan konsep diri akademiknya sehingga bisa terkontrol oleh konselor, sebagaimana disampaikan oleh Kelly, Kim, dan Frangklin (2008:12) Pendekatan SFBC sangat sesuai untuk konselor sekolah dan seting sekolah, karena pada pendekatan ini koselor sekolah bisa berkolaborasi dengan siswa untuk menyelesaikan masalahnya yang berfokus pada pencarian solusi dan dengan solusi tersebut mengarahkan siswa untuk melakukan perubahan hidup yang lebih positif.

Menurut konsep di atas dengan pendekatan ini maka konsep diri akademik tersebut sangat perlu untuk ditingkatkan dengan suatu perubahan perubahan pada diri individu tersebut. Pendekatan Solution-Focused Brief Counseling (SFBC) mempecayai dengan perubahan yang berkesinambungan akan membuat siswa bisa meningkatkan konsep dirinya yang lebih positif, seperi yang disampaikan oleh Bannink (2007:88) Proses perubahan yang berkesinambungan, stabilitas adalah ilusi. Pertanyaannya adalah bukan apakah tetapi ketika perubahan akan terjadi. Klien dapat membantu dalam membuat pemenuhan diri yang positif.

Dengan demikian untuk meningkatkan konsep diri akademik harus segera ditingkatkan karena konsep diri akademik yang kurang positif akan mempengaruhi hasil belajar siswa. Konsep diri akademik yang merupakan salah satu tugas perkembangan yang harus diselesaikan siswa, maka demikian pendekatan yang digunakan juga seharusnya bisa menyesuaikan dengan seting sekolah. Pendekatan yang sesuai untuk digunakan dalam seting sekolah adalah Solution-Focused Brief Counseling (SFBC), karena pendekatan ini bisa dilakukan sengan singkat karena berorientasi pada pembentukan solusi atas masalah siswa, selain itu pendekatan ini mengutamakan kolaborasi atara konselor dengan konseli untuk merubah konsep diri akademik menjadi lebih positif.

Maka demikian pada penelitian ini bertujuan untuk memberikan pemahaman kepada pembaca untuk segera meningkatkan konsep diri akademik siswa dengan menggunakan pendekatan SolutionFocused Brief Counseling (SFBC) secara efektif.

\section{Konsep Diri Akademik}

Konsep diriakademik penting untuk dirubah menjadi positif karena akan mempengaruhi hasil belajar yang akan dicapai oleh siswa. Sebagaimana disampaiakan oleh Marsh (2003:11) menyatakan bahwa konsep diri akademis dapat membuat individu menjadi lebih percaya diri dan merasa yakin akan kemampuan mereka karena sebenarnya konsep diri akademis itu sendiri mencakup bagaimana, individu bersikap, merasa, dan mengevaluasi kemampuannya.

Konsep diri akademik merupakan suatu bagian dari konsep diri, namun pada konsep diri akademik 
lebih spesifik pada proses pembelajaran, dimana pada domain ini banyak yang melakuakan suatu penelitian untuk meningkatkannya (Hardy, 2013:550). Menurut Lent, Brown, dan Gore sebagaimana yang dikutip oleh Cokley (2000:149) konsep diri akademik didefinisikan sebagai suatu sikap, perasaan dan persepsi yang menjadi satu dalam suatu kemampuan akademik dan integensi akademik. Sedangkan Mars yang sebagaimana dikutip oleh Samiroh dan Muslimin (2015:72) segala sesuatu yang mengacu pada persepsi dan perasaan siswa dengan dirinya yang berhubungan dengan akademik.

Pernyataan di atas dikuatkan kembali dengan pendapat dari Shevelson dan Bolus sebagaimana dikutip oleh Saifullah (2015 : 251) mendefinisikan konsep diri akademik adalah suatu penilaian yang dilakukan oleh siswa mengenai dirinya berkaitan dengan kemampuan yang mencangkup persepsi dan perasaan mengenai penerimaan diri, kepercayaan diri, dan penghargaan diri yang mencangkup bidang akdemik yang yang digeluti di sekolah.

Siswa yang memiliki konsep diri yang tinggi menurut Rauh (dalam Manik, Radjah, dan Triyono, 2017:495) konsep diri akademik positif memiliki ciriciri (1) siswa memiliki keyakinan dan kemampuan dalam mengatasi suatu permasalahan, (2) siswa memiliki kasadaran bahwa diluar dirinya tidak selalu menyetujui setiap perasaan, keinginan maupun perilakunya, (3) siswa yang mampu memperbaiki diri, (4) siswa memiliki kepercayaan diri, dan (5) siswa memiliki tipe menerima pujian tanpa rasa malu.

Namun menurut beberapa penelitian konsep diri akademik siswa menjadi kurang posistif. Hal tersebut menurut Argyle, sebagaimana dikutip oleh Budiarsih dan Zen (2016:115) karena terdapat empat faktor yang sangat berkaitan yang berpengaruh terhadap perkembangan konsep diri, yaitu reaksi dari orang lain, pembandingan dengan orang lain, peranan seseorang dan identifikasi terhadap orang lain. Sedangkan dari penelitian yang dilakukan oleh Budiarsih dan Zen (2016:116) menyimpulkan bahwa konsep diri akademik negative siswa muncul akibat adanya perbandingan dengan teman-teman yang lebih pintar. Perbandingan yang dibuat siswa merupakan perwujudan evaluasi negatif siswa terhadap dirinya yang menyebabkan perilaku negatif pula.

Pernytaan di atas juga dikuatkan oleh hasil penelitian dari Manik, Radjah, dan Triyono (2017:500-502) bahwa konsep diri pada siswa mengalami suatu penurunan karena adanya ketakutan murid terhadap sikap guru yang mengajar, belajar dianggap oleh siswa menjadi salah satu sebab berkurangnya waktu bermain dan bersosialisasi, karea fasilitas belajar yang kurang memadai, tidak ada rasa bangga dengan hasil belarnya, dan tidak ada pengaturan waktu untuk belajar.
Dari beberapa konsep di atas ada bebera faktor yang menjadikan konsep diri akademik siswa menjadi kurang. Menurut Penelitian Cokley (2000:150) menyatakan faktor yang mempengaruhi konsep diri akademik, yaitu (1) Kemampuan adaptasi siswa terhadap lingkungan sosialnya, (2) Kemampuan interaksi yang dimilikinya dan nilai pembandingan dengan rekan disekelilingnya, (3) Perbedaan gender, dan (4) Status kelas dalam kemampuan pembelajaran.

Sedangkan fakor timbulnya konsep diri yang kurang positif manurut Shavelson (dalam Saifullah, 2015:253-256) dan Marsh (dalam Samiroh dan Muslimin, 2015:73) yaitu (1) kepercayaan diri, (2) penerimaan diri, (3) penghargaan diri, dan (4) lingkungan akademik.

\section{Solution-Focused Brief Counseling (SFBC)}

Konsep diri akademik merupakan salah satu tugas perkembangan yang harus diselasaikan oleh siswa pada masa belajar di sekolah. Dengan menrunnya konsep diri akademik maka akan mempengaruhi hasil belajar dari siswa. Maka demikian perlunya suatu intervensi yang tepat untuk dilakuakn guna meningkatkan konsep diri akademik dan bisa digunakan dalam seting sekolah.

Pendekatan yang sesuai untuk meningkatkan konsep diri akademik dan bisa digunakan dalam seting sekolah yaitu dengan pendekatan SolutionFocused Brief Counseling (SFBC). Konsep tersebut disampakan oleh Mulawarman (2014:71) model pendekatan Solution-Focused Brief Counseling sesuai untuk diterapkan pada seting sekolah, karena pada pendekatan ini berfokus pada kelebihan siswa daripada kelemahannya, dengan waktu yang tidak terlalu panjang, penekanan konseling pada solusi, dan ketercapaian tujuan.

Pada pendekatan Solution-Focused Brief Counseling $(S F B C)$ ini berfokus pada pencarian solusi untuk mengatasi masalah dan melakukan suatu perubahan untuk bisa menjadi pribadi yang berkembang. Sama halnya konsep dari Shazer (dalam Sobhy dan Cavallaro, 2010:2) menyampaiakan bahwa klien memiliki kemampuan yang diperlukan dan sumber daya untuk berubah dan konseling yang paling aktif ketika membangun solusi yang unik untuk klien.

Disampaiakan juga oleh Shazer (dalam Corey, 2013:400) pendekatan ini tidak menekankan pada sebab pemecahan masalah dan tidak menekankan pada hubungan antara sebab permasalahan dan solusi. Sehingga pada pendekatan ini konseli akan diajak untuk mencari solusi supaya mampu untuk mencapai tujuan yang diinginkan. 
Selain pendekatan diberikan dengan waktu yang singkat, pendekatan ini juga tepat dilakukan oleh para konselor sekolah sebagaimana disampaikan oleh Kelly, Kim, dan Frangklin (2008:12) Pendekatan SFBC sangat sesuai untuk konselor sekolah dan seting sekolah, karena pada pendekatan ini koselor sekolah bisa berkolaborasi dengan siswa untuk menyelesaikan masalahnya yang berfokus pada pencarian solusi dan dengan solusi tersebut mengarahkan siswa untuk melakukan perubahan hidup yang lebih positif.

Pada dasarnya penggunaan pendekatan memberikan siswa untuk leluasa melakukan suatu perilaku perubahan dan perilaku yang berbeda sesai dengan tujuan. Selain hal tersebut, siswa juga ditutut dengan adanya kurikulum pendidikan yang harus mereka selesaikan pula sehingga perlu waktu yang cepat untuk menyelesaikan masalahnya. Juga dengan waktu yang terbatas pula yang dimiliki oleh konselor, dengan pendekatan ini maka konselor bisa berkolaborasi juga dengan stick holder untuk menyelesaikan masalah yang berfokus pada solusi. Pendektan ini juga memiliki asusmsi dengan mengarakan kepada penemuan solusi maka siswa mampu untuk menyelesaikan masalahnya secara mandiri ( Kelly dkk, 2008; Mulawarman, 2014).

Sehingga dengan berbagai konsep di atas, pendekatan Solution-Focused Brief Counseling $(S F B C)$ dirasa efektif untuk menangani konsep diri akademik karena konsep diri akademik juga seharusnya bisa ditingkatkan oleh siswa dalam waktu yang singkat supaya siswa bisa segera mengejar ketertinggalannya dalam proses belajar. Dengan berorientasi pada solusi pendekata ini bisa secara singkat merubah individu untuk meningkatkan konsep dirinya menjadi lebih positif. Dengan adanya kolaborasi dengan konselor dan stick holder sehingga bisa mengotrol perubahan yang berkesinambungan tersebut.

Pendekatan Solution-Focused Brief Counseling $(S F B C)$ seperti yang disampaikan di atas karena memiliki konsep dasar yang diajarkan oleh Steve de Shazer dan Insoo Kim (dalam Connie dan Metcalf, 2009:5-12) konsep dasar Solution-Focused Brief Counseling (SFBC) yaitu (1) if it is not broken, don't fix it (jika tidak ada yang buruk, jangan perbaiki). (2) if something is found to be working, do more of it (jika melakukan pekerjaan, lakukan sesuatu yang lebih); (3) if something is found to not be working, do something different (jika sesuatu tidak bekerja, lakukanlah hal yang berbeda); (4) small steps can lead to big changes (langkah-langkah kecil bisa membewa suatu perubahan yang besar); (5) the solution is not necessarily related to the problem (solusi yang tidak selalu berhubungan dengan masalah); (6) the language for solution development is different from language needed to describe a problem (bahasa untuk mengembangakan solusi berbeda dengan bahasa untuk mengembangkan masalah).

\section{Asumsi dan Tujuan Solution-Focused Brief Counseling (SFBC)}

Pada pendekatan Solution-Focused Brief Counseling (SFBC) memberikan suatu penjelasan bawasannya bagaimana sesorang bisa berubah dan bagaimana mereka mencapai tujuan yang diharapkan. Manurut Wallter dan Paller (dalam Corey, 2013:401) menyatakan beberapa asumsi dasar dari pendekatan Solution-Focused Brief Counseling (SFBC) yaitu pertama, individu yang datang ke terapi mampu berprilaku efektif meskipun mereka menunjukan perilaku keefektivan ini sementara terhalangi oleh pandangan negative.

Kedua, ada keuntungan-keuntungannya fokus terhadap hal positif untuk menemukan solusi dan pandangan ke depan. Ketiga, ada pengecualian pada setiap problem sebagai petunjuk menemukan solusi. Keempat, klien sering hanya menampilkan satu sisi dari diri mereka, SFBC mengajak klien untuk menyelidiki sisi lain dari cerita yang sedang mereka tampilkan.

Kelima, Perubahan kecil adalah cara untuk mendapatkan perubahan yang lebih besar. Keenam, Klien yang ingin berubah mempunyai kapasitas untuk berubah dan mengerjakan yang terbaik untuk membuat suatu perubahan itu terjadi. Ketujuh, Klien dapat dipercaya pada niat mereka untuk memecahkan problem.

Asumsi-asumsi menurut konsep Bannink (2007:88-89) yaitu konselor akan menyakinkan konseli yang konsep dirinya kurang positif untuk bisa berubah menjadi lebih positif, konseli yang berkonsep diri rendah diajak untuk melakukan perubahan pada dirinya menjadi lebih positif, untuk menikatkan konsep diri yang kurang positif konseli bisa memaknai perubahan-perubahan pada dirinya walau masih sedikit. Yakin bahwa konseli bisa merubah konsep dirinya yang negatif menajdi positif, konseli diarahkan untu fokus pada tujuan untuk menjadikan dirinya memiliki konsep diri yang positif, dan kondisi nyata konseli bisa membaantu konseli untuk merubah kopsep diri akademiknya.

Dalam pelaksanaan pendekatan ini tentunya ada beberapa tujuan, maka demikian tujuan dari pendekatan ini. Menurut west, Bubenzer, Smith, dan Hamm (dalam Glading, 2015:285) dan Palmer (2011:556) yaitu (1) mengidentifikasi dan memanfaatkan sepenuhnya kekuatan dan kopetensi yang dibawa oleh klien. Seperti menetahui tentang sebab konsep diri akademiknya menjadi negatif, (2) Menyadari pengecualian di dalam dirinya pada saat ia bermasalah, seperti menyadarkan bahwa dirinya memiliki suatu perbedaan untuk merubah konsep dirinya yang negatif, (3) mengarahkan klien pada solusi terhadap sitiasi pengecualian tersebut, sehingga konseli dalam situasi tertentu bisa menemukan solusi untuk meningkatkan konsep dirinya, dan (4) 
menolong klien berfokus pada hal-hal yang jelas dan spesifik untuk meningkatkan konsep dirinya.

\section{Langkah-Langkah Pendekatan Solution-Focused Brief Counseling (SFBC)}

Tahapan pendekatan Solution-Focused Brief Counseling (SFBC) agar bisa digunakan dengan maksimal. Tahapan tersebut menurut Seligman (dalam Mulawarman, 2014:70) sebagai berikut :

1. Establishing Relationship (Membangun Hubungan Baik), membina hubungan baik antara konselor dengan konseli untuk berkolaborasi, dengan menggunakan topik netral sehingga bisa membangun kemungkinan-kemungkinan dan kekuatan konseli untuk mebangun solusi.

2. Identifying a solvable complaint (Mengidentifikasi Permasalahan yang Bisa Ditemukan Solusinya), memberikan pertanyaan kepada konseli sehingga mengetahui penyebab konsep diri akademiknya menjadi negatif, dan mengetahui latar belakang konseli sehingga bisa memberikan kemungkinankemungkinan yang bisa digunakan sebagai solusi untuk merubah konsep diri akademiknya menjadi positif.

3. Establishing goals (Menetapkan Tujuan), memberikan pertanyaan keajaiban kepada konseli seperti "seandainya kamu memilki nilai yang baik apa yang kamu rasakan ?" sehingga untuk mengetahui tujuan konseli untuk meningkatkan konsep diri akademiknya.

4. Designing and Implementing Intervention (Merancang dan Menetapkan Intervensi), pada tahap ini konseli diberikan intervensi untuk meningkatkan konsep diri akademiknya, seperti dengan pengecualian situasi apa yang bisa membuat dia bisa menemunkan solusi agar meningkatnya konsep diri akademiknya dan dijadikan tugas untuk konseli.

5. Termination, Evaluation and Follow-up (Pengakhiran, Evaluasi, dan Tindak Lanjut), pada tahapan ini konselor memberikan pertanyaan berskala untuk mengetahui peningkatan konsep diri akademik siswa pada saat sebelum dan setelah konseling. Melakukan perrjanjian konseling kebali jika tujuan peningkatan konsep diri tersebut masih dirasa perlu.

Teknik-Teknik Pendekatan Solution-Focused Brief Counseling (SFBC)

Untuk lebih efektif dalam penggunaan pendekatan ini maka perlu suatu treament untuk membatu konseli dalam mencari solusi atas masalahnya, menurut Corey, Seligman dan Macdonald, sebagaimana dikutip oleh Mulawarman (2014: 70) terdapat tiga teknik dasar yaitu Exception-finding questions (Questions discovery exception), Miracle questions
(Question miracle), and Scaling questions (Questionscale).

1. Exception-finding questions (Questions discovery exception) (Kalimat Pengecualian), pertanyaa tentang waktu atau keadaan yang yang bisa membuat konseli merasakan terbebas dari masalahnya, dengan demikian bisa membangun pengecualian yang dilakukan konseli untuk melakukan perubahan. Seperti pada saat-saat bagaimana konseli bisa untuk nyama dalam proses belajar, sehingga untuk meningkatkan konsep diri akademiknya.

2. Miracle questions (Question miracle) (Pertanyaan Keajaiban), pertanyaan pengandaian pada konseli apabila masalahnya bisa terselesaikan dan apa yang akan dia lakukan untuk mewujudkan hal tersebut, teknik ini mendorong untuk mengetahui tujun konseling yang diinginkan oleh konseli. Seperti "Bagaimana perasaanmu bila disemester ini nilai mu meningkat ?" sehingga mengetuhui tujuan dan menemukan solusi untuk meningkatkan konsep dirinya dengan memberikan target untuk melakukannya.

3. Scaling questions (Question-scale) (Pertanyaan Berskala), pertanyaan berskala memungkinkan konseli untuk lebih memperhatikan apa yang mereka telah lakukan dan bagaimana meraka dapat mengambil langkah yang akan mengarahkan pada perubahan-perubahan yang mereka inginkan, sehingga perubahannya bisa diamati. Seperti "pada sekala 0 berarati kamu merasa tidak yakin dengan kemampuanmu meraih target belajarmu dan 10 kamu sangat yakin bisa mencapai target belajarmu, sekiranya kamu pada angka berapa ?"

Adapun teknik tambahan yang disampaikan oleh Corey (2013:407) sebagai berikut :

1. Formula First Session Task (FFST) (Teknik Memberikan Tugas pada Sesi Utama), Terapi ini merupakan suatu terapi yang memberikan pekerjaan rumah kepada konseli pada awal konseling maupun disesi konseling selanjutnya. Pada teknik ini maka konseli bisa mengemabangkan dan mencari solusi dengan melakukan suatu pengamatan tentang tujuan kedepan yang ingin dia capai. Seperti "kalau demikian besuk bererti kamu membuat jadwal belajar sehingga belajarmu akan teratur ?" sebagai salah satu pacu agar bisa meningkatkan belajarnya sehingga konsep dirinya juga meningkat.

2. Therapist Feedback to Clients ( Terapi Umpan Balik Untuk Konseli), Pada saat memberikan suatu umpan balik maka terdapat tiga hal yang perlu disampaikan, yaitu memberikan pujian, kalimat penjembatan untuk meberikan tugas, dan menyarankan tugas, dengan memberikan umpan balik kepada konseli bertujuan untuk memberikan merekan kesempatan melakukan lebih banyak hal dan melakukan hal yang berbeda untuk 
meningkatkan kemungkinan-kemungkinan untuk tercapainya tujuan mereka. Seperti " luar biasa kamu bisa menemukan solusi utuk meningkatkan konsep diri akademikmu dengan membuat peta target belajar, dengan demikian pertemua selanjutnya kita bahas ya target belajarmu?"

Menurut Kelly, Kim, dan Franklin (2008:19) menjelaskan beberapa teknik yang bisa digunakan pada pendekatan SFBT, sebagai berikut :

1. Compliments Count ( Memberikan Pujian), Pada teknik ini konselor memberikan suatu pujian kepada konseli tentang kemajuan dan perubahanperubahan kecil yang telah dilakukan oleh konseli yang sesuai dengan tujuan konseling, sehingga konseli akan bersemangat untuk melakukan suatu perubahan-perubahan kembali. Seperti " wah kamu hebat ternyata kamu sudah mau mencoba untuk mengerjakan PR tepat pada waktunya"

2. Coping Questions (Mengatasi Pertanyaan), Pada teknik ini konselor bisa memberikan pertanyaanpertanyaan kepada konseli untuk berkolaborasi sehingga konseli bisa mengeksplorasi sehingga bisa mengubah situasi mereka. Dengan ini pula akan memberikan intensitas emosional pada konseli dengan demikian bisa membantu konseli untuk menemukan solusinya sendiri.Seperti "nah, nak mari kita bersama-sama untuk menemukan solusi sehingga kamu bisa kembali semangat untuk belajar, nah untuk itu sekiranya hal kecil apa yang bisa kamu lakukan?"

\section{Penutup}

Mendasar pada pembahasan di atas maka dapat disimpulkan mengenai pendekatkan Solution-Focused Brief Counseling (SFBC) untuk meningkatkan konsep diri akademik sebagai berikut.

Konsep diri akademik pada siswa kali ini sudah mulai kurang positifnya karena kurangnya percaya diri, penerimaan diri, penghargaan pada dirinya, hingga lingkungan yang tidak efektif bagi pembelajaran dirnya. Apabila hal ini dibiarkan maka akan membuat siswa tidak bisa meraih prestasi belajar yang maksimal.

Dengan demikian permasalahan konsep diri ini harus segera untuk diselesaikan dengan cepat agar siswa bisa untuk menyesuikan proses belajar dan mengejar ketinggalan akibat konsep diri yang rendah.

Untuk meningkatkan konsep diri akademik siswa yang rendak maka perlunya ada treatment yang tepat sehingga efektif bagi siswa yang dimana sesuai dengan seting sekolah, karena konsep diri ini merupakan salah satu tugas perkembangan yang harus diselesaikan oleh siswa dalam masa belajarnya.

Pendekatan yang bisa digunakan dalam seting sekolah dan dalam waktu yang singkat yaitu menggunakan Solution-Focused Brief Counseling $(S F B C)$, tepat dilakukan disekolah karena pendekatan ini beroientasi pada solusi sehingga waktu yang digunakan untuk meningkatkan konsep diri akademik bisa lebih singkat. Sekolah membutuhkan waktu yang singkat agar siswa bisa segera menyesuikan dengan kurikulum dan konselor tidak memiliki waktu yang banyak untuk bertemu dengan konseli.

Namun pada penedekatan ini konselor akan berkolaborasi dengan konseli dan stick holder untuk mengontrol perubahan-perubahan yang berkesinambungan dari suatu perlakuan yang berbeda yang sebagai solusi untuk meningkatkan konsep diri akademik siswa. Dengan demikian konseli bisa secara cepat dan terkontrol untuk meningkatkan konsep diri akademik.

Pendekatan Solution-Focused Brief Counseling $(S F B C)$ bisa dilakukan dalam waktu yang singkat karena pendekat ini berfokus pada perkembanga solusi yang dibangun oleh konseli tidak pada masalah konseli. Pendekat ini juga efektif diterapkan pada seting pendidikan karena pada pendekatan ini berfokus pada kelebihan siswa daripada kelemahannya, dengan waktu yang tidak terlalu panjang, penekanan konseling pada solusi, dan ketercapaian tujuan. Dengan demikian siswa bisa menyesuaikan dengan tuntutan kurikulum pemeblajaran dengan cepat dan efektif pula bagi konselor yang memiliki waktu terbatas.

Mendasar dari kesimpulan di atas saran yang diajukan untuk para pembaca terutama adalah konselor yang berada di sekolah yaitu pentingnya untuk meningkatkan konsep diri akademik siswa dalam waktu yang efektif sehingga siswa bisa segera menyesuikan untuk meraih hasil berlajar yang maksimal, untuk itu maka koselor bisa untuk mempelajari dan mengaplikasikan pendekatan Solution-Focused Brief Counseling (SFBC) sehingga bisa untuk meningkatkan kemampuan siswa untuk menemukan solusi yang digunakan meningkatkan konsep diri akademik dengan waktu yang singkat, dan bisa berkolaborasi dengan siswa sehingga bisa memunculkan kemungkinankemungkinan untuk melakuakan suatu perubahan-perubahan dengan hal yang berbeda.

\section{Daftar Pustaka}

Budiarsih, Anita Putri dan Ella Faridati Zen. 2016. Studi Kasus Konsep Diri Akademik Siswa Sekolah Dasar. Jurnal Kajian Bimbingan dan Konseling 1 (3) : 112-117.

Bannink, F. P. 2007. Solution-Focused Brief Therapy. J Contemp Psychother, 37, 87-94.

Cokley, Kevin. 2000. An Investigation of Academic Self-Concept and Its Relationship to Academic Achievement in African American College Students. Journal of Black Psychology, 26 (2), 148-164. 
Connie, Elliott dan Linda Metcalf. 2009. The art of Solution Focused Therapy. New York : Springer Publishing Company.

Corey, Gerald. 2013. Theory adn Practice Counseling and Psychotherapy (9 $9^{\text {th }}$ edition). Belmont, CA: Brooks/Cole.

Dagnew, Asrat. 2015. The Relationship among Parenting Styles, Academic Self-concept, Academic Motivation and Student ${ }^{6}$ Academic Achievement in Fasilo Secondary School: Bahir Dar, Ethiopia. Science, Technology and Arts Research Journal , 4(3): 215-221.

Feist, Jess dan Gregory J. Feist. 2013. Teori Kepribadian (Theories of Personality). Terjemakan Handriatno. Edisi 7. Jakarta : Salemba Humanika

Flowers, Lawrence O, James E. Raynor, Jr, dan Erin N. White. 2013. Investigation of Academic SelfConcept of Undergraduates in STEM Courses. Journal of Studies in Social Sciences , 5 : 1-11.

Franklin, Cynthia, Kelly Moore, and Laura Hopson. 2008. Effectiveness of Solution-Focused Brief Therapy in a School Setting. Children \& Schools, 30(1) : 15-26.

Glading, Samuel T. 2015. Konseling Profesi yang Menyeluruh (Terjemahan Winarno) (Ed. Keenam). Jakarta : PT. Indeks.

Gudnanto, Anwar Sutoyo, dan Maman Rahman. 2013. Pengembangan Model BK Kelompok Berbasis Islami untuk Peningkatan Konsep Diri. Jurnal Bimbingan dan Konseling, 2(1) : 19-24.

Hardy, Graham. 2013. Academic Self-Concept: Modeling and Measuring for Science. Research in Science Education is the property of Springer Science \& Business Media Dordrecht. 44:549579.

Hurlock, Elizabeth B. 2003. Psikologi Perkembangan : Suatu Pendekatan Sepanjang Rentang Kehidupan (Edisi Kelima). Terjemahan. Jakarta : Erlangga

Isikal, Mine. 2010. A Comparative Study on Undergraduate Students'Academic Motivation and Academic Self-Concept. The Spanish Journal of Psychology 13(2), 572-585.

Kelly, Michael S, Johnny S. Kim, and Cynthia Franklin. 2008. Solution-Focused Brief Therapy in Schools. New York : Oxford University Press
Mandelman, S.D, Mey Tan, S. A Kornilov, R. J Sternberg, \& E. L Grigorenko. 2010. The Metacognitive Component of Academic SelfConcept: The Development of a Triarchic SelfScale. Journal of Cognitive Education and Psychology, 9(1) : 73-86.

Manik, Resmin, Carolina L. Radjah, \& Triyono. 2017. Rendahnya Konsep Diri Akademik Siswa SMP. Jurnal Pendidikan: Teori, Penelitian, dan Pengembangan. 2 (4) : 494-502.

Mulawarman. 2014. Brief Counseling in Schools: a Solution-Focused Brief Counseling (SFBC) Approach for School Counselor in Indonesia. Journal of Education and Practice, 5(21) : 6872.

Marsh, H.W. 2003. A Reciprocal Effects Model of the Causal Ordering of Academic Self-Concept and Achievement. Paper presented at NZARE AARE. Auckland, New Zealand.

Palmer, Stephen (Ed). 2011. Konseling dan Psikoterapi (Terjemahan Haris). Yogyakarta : Pustaka Pelajar

Saifullah. 2015. Hubungan Konsep Diri Akademik Dengan Prestasi Akademik. Jurnal Lisan Al-Hal, 7(2) : 249-258.

Samiroh, dan Zidni Imawan Muslimin. 2015. Hubungan Antara Konsep Diri Akademik Dan Perilaku Menyontek Pada Siswa- Siswi Mas Simbangkulon Buaran Pekalongan. Jurnal Psikologi Islam, 1 (2) : 67-77.

Sobhy, M., \& Cavallaro, M. 2010. Solution-focused brief counseling in schools: Theoretical perspectives and case application to an elementary school student. http://counselingoutfitters.com/vistas/vistas10/A rticle_81.pdf. 